\title{
蛋白構造のゆらぎ（重水素交換）
}

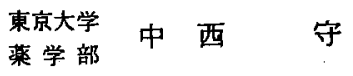

タンパク質のもっている生物活性がタンパク分子の どのような權造と物性に起因しているか，換言すれば， 活性の発現と棈造との関保を明らかにするためには， 活性発現に到るまでのタンパク構造の動的過程の詳細 を理解しなければならないであろう.タンパク質の分 子棰造（いわゆる高次棈造）については，現在われわ れはかなり詳細な知識を既にもっている，X線結晶解 析により結晶構造が解明されたタンパク買の種類は数 十にのぼっているし，溶液中の構造についてむ結晶中 と類似したものであることを示唆する結果がたくさん 得られている.さらに，それら棰造の溶液中における 熱安定性についても実験結果が蓄積されている.しか し、活性発現の場である native 状態におけるタンパ ク分子の構造の動きについては未だほんの少ししか理 解していない，それは native 状態におけるタンパク 質の構造の動きを測定するのに適した方法がほとんど ないからである。

タンパク倎の同位元素交換法はタンパク中の窒素, 酸素，硫黄などの原子についた水素が水溶液中で比較 的容易に水の水素と交換する性犋を利用してタンパク 質の構造を知ろうとするものである。その上うな水素 の交換速度はタンパク質の高次構造の形成によって非 常に大きい影留を受ける。それ中え，タソバク質が本 来動的性質をそなえたものならば同位元素との交換反 応の追跡によって構造の摇動（ゆらき）に対する知識 を得ることができると期待される、つまり、この方法 は native 状態におけるタンパク質の動的構造を知る 数少ない方法の一つにあげることができる．

タンパク貎についての同位元素交換反応の測定は 1950 年代の初頭に Linderstr $\phi \mathrm{m}$ - Lang に上り始め られた2. Linderstr $\phi \mathrm{m}$ - Lang の考えの中にはすでに 動的構造の概念が存在していたが, ${ }^{3}$ 動的構造の測定手 段として関心が高をり，評価が確立したのは比較的最 近である.7) タンパク質の分子棰造に対する関心が静 的なものから動的なものに移行しつつある現象の一つ であろう: 我々はここ数年来, 郝外線吸収スペクトル
を中心にした一連の重水素交換反応の测定により，タ ンパク質の棬造のゆらきに関する研究を行なってきた。 ここでは、これまでの結果を中心にしてタンパク質の 構造のゆらぎの研究の現況を紹介する？

\section{1. ペプチド水素の交換}

タンパク質の同位元素交喚法の対象としてはペプチ ド水素と何種かの側鎖の水素がある。ペプチド水素の 交換反応は Linderstr ク質の構造研究にしばしば用いられてきた?゙を゙の交换 反応には Englander の考案したせファデックスのカラ ムクロマトグラフィーを用いてタンパク中のトリウム と水素の交換を追跡する方法 ${ }^{10)}$ とBlout らの提案した 赤外線吸収スペクトルで重水素との交換を追跡する方

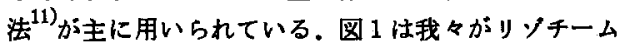
の重水素交換反応を赫外線吸収スペクトルによって測 定したものである゙）ペプチド水素の重水素化によるア

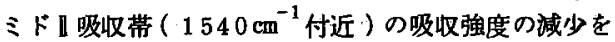
アミドI吸収帯 $\left(1650 \mathrm{~cm}^{-1}\right.$ 付近）の強度を基淮にし て測定し交換した水素の量を求める。この方法ではぺ プチド水素の交換だけを区別して測定できる利点があ る.

タンパク質の同位元素交換反応において，ゆっくり と交換する水素はタンパク搆造の内部にあり溶媒と接 しにくくなっているものとか水素結合しているものと 想像してもそれ程おかしくないであろう。たとえば， 初期には中っくりと交換する水素の量は $\alpha$ ーヘリック ス含量に等しいのではないかと考えられたことがある。” これには Pauling, Coreyの $\alpha$ ーヘリックスのモデ $ル^{13)}$ が大きく影響していたといえる。しかしこれに 対してては霂足な解答が得られなかった。タンパク嵮が

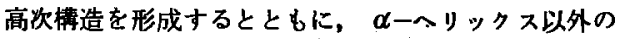
水素結合も存在することからして，简単ではなかった のである。

最近，我々はタンパク蛽のX線結晶解析の結果をふ まえて，交換反応においてゆっくりと交換する水素の 


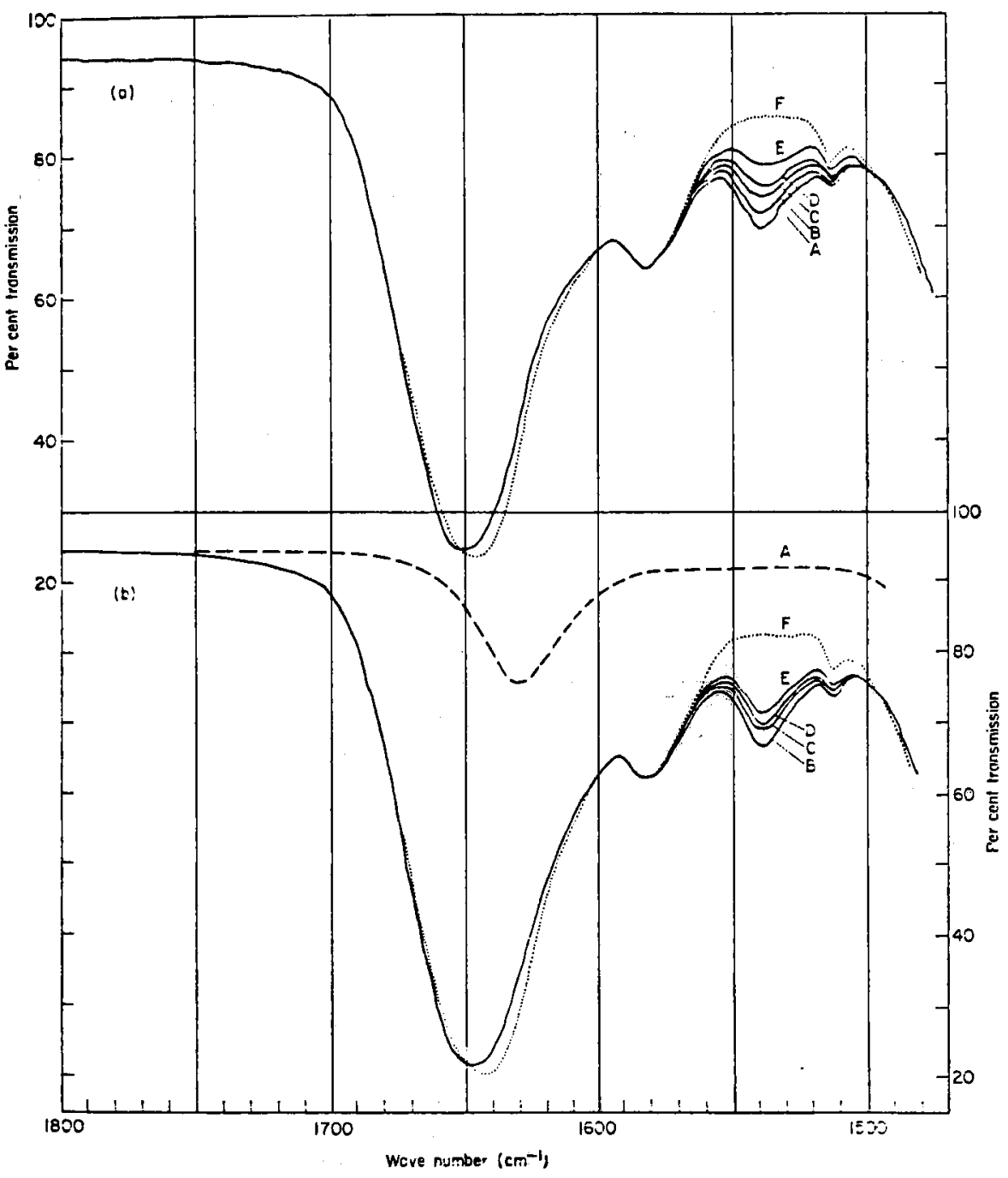

图1重水素交换に上る赤外線吸収スペクトルの贺化を示す図.

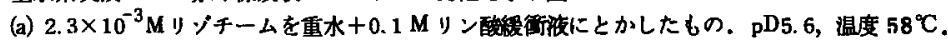

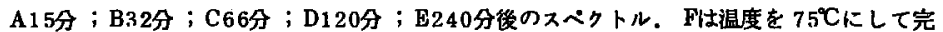
全に重水素化したもの.

(b), (a)にNーアセチルーDーダルコサミンのテトラマーを0.01M添加したもの. A仕テト ラマー. B か.5 Fはリソチーム+テトラマーのもの. B19分；C60分；D 120 分；日240 分後のスペクトル．Fは完全に重水素化したしの. 
性買についての詳細な检討を行なった. ミオグロビン， $\alpha$ ーキモトリプシン, ウシ脺臟トリプ シンインヒビター，コンカナバリン $\mathrm{A} の 5$ 種類の X楾 結晶解析のなされているタンパク質について赤外線吸

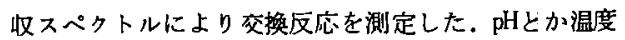
などの溶媒条件を変化させても常に一定量なゆっくり と交換する水素がそれぞれのタンパク質に存在するこ とがかかった。リソチームの交換反応を図 2 に示した）
映して微妙にその速度定数が異なる。しかし，実際に は数個程度の一欢反応の和として一般には近似される。 一方, Englander らはミオグロビンを用いてペプ チド水素の水素結合していない㫣に相当するむのの交換速 度がランダムコイル状態のポリペプチドの交換速度と よく一致することから，ゆっくりと交換する水素が水 素結合したものであることを明らかにしている.

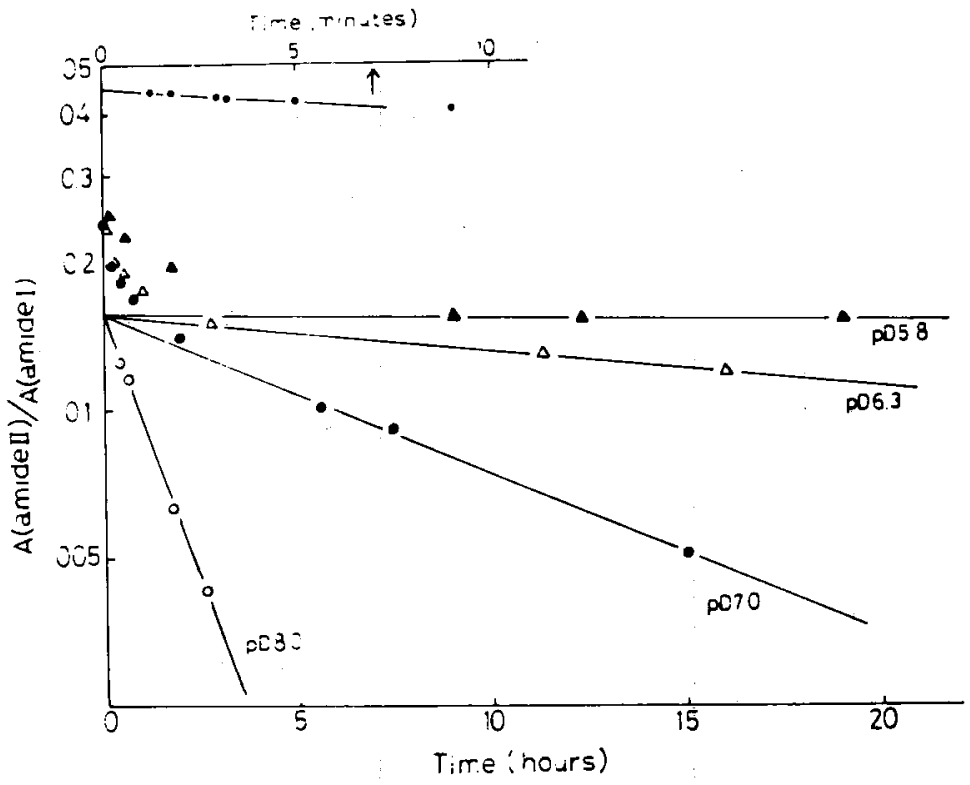

图 2 リジチームの重水溶液中におけるペプチド水素の重水素反応の片対数プロット.

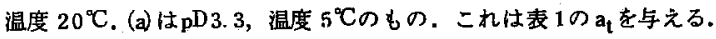

また，表1から明らかなように，これらは結晶解析から求ま っている分子内のペプチド閒の水妻結合した水素の量とよく 一致している! ものにこの手法を適用し，推定したペプチド間の水素 結合の数を表わしている。もちろん，ここで示した水 素結合した水素の交換速度は個々のサイトの性翼を反

\section{2. 交換反応の機構亡構造のゆらき}

ゆっくりと交換する水素が水素結合したものである なら，交換反応を測定すれば棈造のゆらぎに対する情 報を与えてくれると考えられる.すなわち，LinderstrømーLang とその共同研究者であった Hvidtらは 
表1タンパク留中のペプチドーペプチド間の水素結合の数の決定

\begin{tabular}{|c|c|c|c|c|c|c|}
\hline \multirow[b]{2}{*}{$\therefore$} & \multicolumn{2}{|c|}{$\begin{array}{l}\text { 時間ゼロの } \\
\text { アミド】/ノミドI } \\
\text { の強度比 }\end{array}$} & \multirow{2}{*}{$a_{i} / a_{t}$} & \multirow{2}{*}{$\begin{array}{l}\text { 交換 可能な } \\
\text { 全ペプチド } \\
\text { 数 }\end{array}$} & \multicolumn{2}{|c|}{$\begin{array}{l}\text { ペプチドーペプチド } \\
\text { 間の水素結合の数 }\end{array}$} \\
\hline & $\begin{array}{c}\text { 全ペプチド } \\
\vdots\left(a_{t}\right)\end{array}$ & 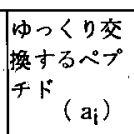 & & & 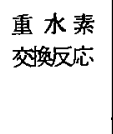 & $\begin{array}{l}\text { X線結晶 } \\
\text { 解 析 }\end{array}$ \\
\hline 厶 & 0.450 & 0.155 & $34.4 \%$ & $126^{16)}$ & $44^{4)}$ & $44^{26)}$ \\
\hline ミオ グ ロ ビン & 0.450 & 0.355 & 74.4 & $148^{17)}$ & $109^{24)}$ & $108^{27)}$ \\
\hline$a$ - & 0.450 & 0.235 & 52.2 & $229^{18)}$ & 120 & $121^{28)}$ \\
\hline ウシ膵䔍トリプシンインヒビター & $(0.450)$ & 0.170 & 37. 8 & $53^{19)}$ & 20 & $20^{29}$ \\
\hline$\exists$ ン カ $+\therefore$ J $ン A$ & $(0.450)$ & 0.175 & 38. 9 & $226^{20)}$ & 88 & $(86)^{20)}$ \\
\hline$a-ラ \Rightarrow \vdash>ル フ ゚ ン$ & 0.4 .50 & 0.130 & 28. 9 & $120^{21)}$ & $35^{25)}$ & \\
\hline 大豆トリプシンインヒビター & 0.450 & 0.220 & 48. 9 & $170^{22)}$ & $83^{(F)}$ & \\
\hline 放線菌のズブチリシンインヒビター & 0.460 & 0.140 & 30.2 & $104^{23)}$ & 32 & \\
\hline
\end{tabular}

同位元素交換の機構として次の式を仮定して提出した ${ }^{9 ）}$

$$
N_{i} \underset{k_{z i}}{\stackrel{k_{i i}}{\rightleftharpoons}} D_{i} \stackrel{k_{\mathrm{e}}}{\longrightarrow} D_{i}^{*}\left(\rightleftharpoons N_{i}^{*}\right)
$$

ここで $N_{i}$ というのは水素結合した native 状態の構 造を表わしており，この状態からの重水素との交換は 無視できる程ゆっくりである， $D_{i}$ は水素結合が壊れ た構造でありこの状態からは完全にランダムなペプ チド鎖の交換反応速度定数 $k_{\boldsymbol{e}}$ で交換が進行できると 考える， $D_{i}^{*}, N_{i}^{*}$ は重水素化されたそれぞれの構造 を表わす. 各々のペプチドの NHを区別するために添 字 $i か ゙$ 付けてある. $k_{e}$ はテミノ酸配列にはそれ程影 響されないので,゙゚ンダムコイルのポリーDLーフラ キンのもので代表さすと，

$$
\begin{aligned}
k_{e}=50\left(10^{-\mathrm{pH}}+10^{\mathrm{pH}-6.0}\right) \\
10^{0.05(\mathrm{t}-20)} \mathrm{min}^{-1}
\end{aligned}
$$

の実験式が使えるぎここで である.(1)式において $D_{i} \longrightarrow D_{i}^{*}$ の交換速度が $N_{i}$ $\rightleftharpoons D_{i}$ の構造変化の速度より速く,

$$
k_{1 i}+k_{2 i} \ll k_{e}
$$

が成立している場合には，重水素交換速度定数 $k_{i}$ は

$$
k_{i}=\frac{k_{1 i} k_{e}}{k_{1 i}+k_{2 i}+k_{e}}=k_{1 i}
$$

となり，直接 $N_{i} \longrightarrow D_{i}$ の構造変化の速度定数を表 わす（ $\mathrm{EX}$ 機構と呼ばれている）。

一方, $N_{i} \rightleftharpoons D_{i}$ の構造変化の速度が $D_{i} \longrightarrow D_{i}^{*}$ の交換速度上り速く

$$
k_{1 i}+k_{2 i} \gg k_{e}
$$

が成立している場合には, 重水素交換速度定数 $k_{i}$ は,

$$
\begin{aligned}
k_{i}=\frac{k_{1 i}}{k_{1 i}+k_{2 i}} \cdot k_{e} & =\frac{\left[D_{i}\right]}{\left[N_{i}\right]+\left[D_{i}\right]} k_{e} \\
& =r_{i} k_{e}
\end{aligned}
$$

となる。ただし， $r_{i}$ は $D_{i}$ 状態の割合である( $\mathrm{EX}_{2}$ 機構と呼ばれている)。

それゆえ，bし(1)式を同位元素交換反応の機構に探用 できるなら，交換反応の测定により構造変化の速度や $D_{i}$ 状態の割合を求めることができるはずである。し かも，反応速度の測定なので native 状態でのわずか な量の構造変化に対するそれらの值を求めることがで きると期待される゙

我々はまず(1)式の機構が要当かどうか検討してみた。 (1)式を仮定才れば交換反応より求まる $N_{i} ， D_{i}$ 状態の 割合や速度定数を他の物理化学的手段によって求まる ものと比較したわけである.

リゾチームの重水素交換反応を $\mathrm{pH}$ 温度を一定にし て $\mathrm{LiCl}$ の濃度を変えて測定すると，44 個のゆっく 
りと交換する水素はかなりの部分が一個の一次反応で 交換するとして近似できる。その結果は図 3 に示した。 この一次反応の速剫定数から棒造変化が速く(5)式が成 立しているとして，D形の割合を(6)式を用いて求的て みた。その結果は $\mathrm{LiCl}$ の澧度に対し図 4 のXのよう

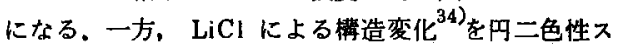
ペクトルの $222 \mathrm{~nm}$ のモル棈円率の変化により測定 し、 $D$ 形の割合を求めると，図 4 の (水溶液中)，

○(重水溶液中)のようになった，D含量について円 二色性と交換反応速度の両方から求めた結果はよく一 致していることが実験的に示された。このことは重水 素交換反応機構を(1)式で充分説明できることを示して おり，同時に構造変化の速度が速いことがわかる？

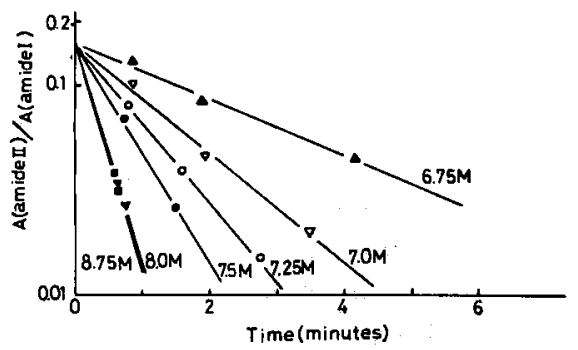

図3高灌度のLiCl溶液中でのりソ゚チームの重水素交換反 店の図. pD5. $0,20^{\circ} \mathrm{C}$.

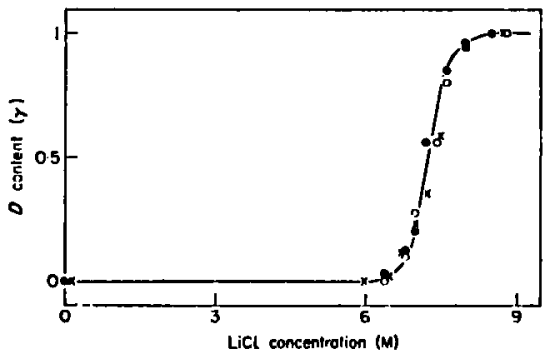

図4リソチームのD形の割合( $(r) を \mathrm{LiCl}$ 瀑度に対し 表わしたもの.(凶)交換反応上り(6)式を用いて計

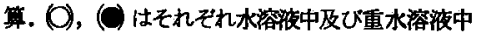
の円二色性スペクトルから求めたもの.

このようにいったん(1)式と(6)式の関係を仮定すると， 特間をかけて $k$ の小さい值を測定すれば，小さいケの 值も求めることができる。これを使ってリッチーム,
イーラクトアルブミン ${ }^{25)}$ や放線菌加らとれたズブチリ シンのインヒビター（ S - SI）の重水素交換反応の 温度変化の結果を解析すると興味深い現象が見い出さ れた。

ズブチリシンのインヒビターを例にして説明する。 $D$ 形の割合が小さい $\left(D_{i} \ll 1\right)$ とき,

$$
r_{i}=\frac{\left[D_{i}\right]}{\left[N_{i}\right]+\left[D_{i}\right]} \div \frac{\left[D_{i}\right]}{\left[N_{i}\right]}=k_{i}
$$

だから，(5)式が成立する場合，交換反応から平衡定数 ( $[D] /[N])$ が求まる.S-S I のpH 6.4 でゆっく りと交換する 32 個の水素こ関して van't Hoff プロッ トした結果が図 5 である、ムは紫外吸収スペクトルの 測定によって $[D] /[N] の$ 平衡定数を測定した結果. このタンパクは重水中温度 $84^{\circ} \mathrm{C}$ 付近で可逆的な熱 変性をする。 32 個の水素の交換は $65^{\circ} \mathrm{C}$ 以上では一 つの一次反応で進行し，平衛定数口は紫外吸収で求 めたものの延長上にのる。図 5 のプロットから65 ${ }^{\circ} \mathrm{C}$ 以上では $N \longrightarrow D$ 楼造変化のエンタルピーは $\Delta H=185 \mathrm{kcal} / \mathrm{mol}$, エントロピーは $\Delta S=518$ e.u。が得られる。これらの值から転移領城付近 65 $\sim 95{ }^{\circ} \mathrm{C}$ ) では $N \rightarrow D$ 変化は分子全体の棈造変化を 表わしていると考えてよい，一方，60 個の交換反応はその中で交換の速い方が 15 個 ( $\mathrm{B}_{1}$ グ

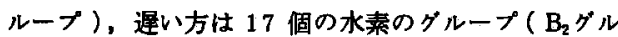
ープ)に大別できる.それゆえ, van't Hoff プロット

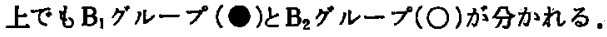
しかも，両者のプロットの傾斜は非常にゆるやかにな り， $65^{\circ} \mathrm{C}$ 以上で観測される棈造変化とは異蜇のもの であることがわかる、 $\mathrm{B}_{1}$ グループの $D$ 状態の見かけの 割合は $25^{\circ} \mathrm{C}, \mathrm{pH} 6.4$ で $2 \times 10^{-6}$ 程度である. $\mathrm{B}_{2}$ グ ループの $D$ 状態は $55^{\circ} \mathrm{Cで} 9 \times 10^{-8}$ 程度であり, 25 “Cではさらに小さい值になると考えられる（ $\mathrm{pH} \mathrm{8.75，}$

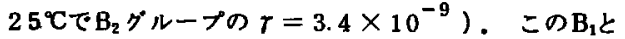
$\mathrm{B}_{2}$ は交換反応の進行に伴う赤外スペクトルのアミド】

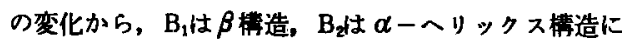
相当すると考えられる ${ }^{31)}$

ところで， $\mathrm{B}_{1}$ グルーブ中の 15 個の $\mathrm{NH}$ 基にとって の $D$ 形分子は $N \rightleftharpoons D$ 変化の $\Delta H=2.9 \mathrm{kcal} / \mathrm{mol}$, $\Delta S=-16.8 \mathrm{e}$.u. になる．このような一見奇妙な

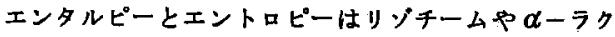
トアルブミンでも同様に見られた. 25)つまり常温付近 の溶液中では， $N \longrightarrow D$ の変換によって，エンタルピ 一はたかだか水素結合が 1，2 個切れる分ぐらいしか増 加せず, しかもェントロピーは減少する。この值は水 


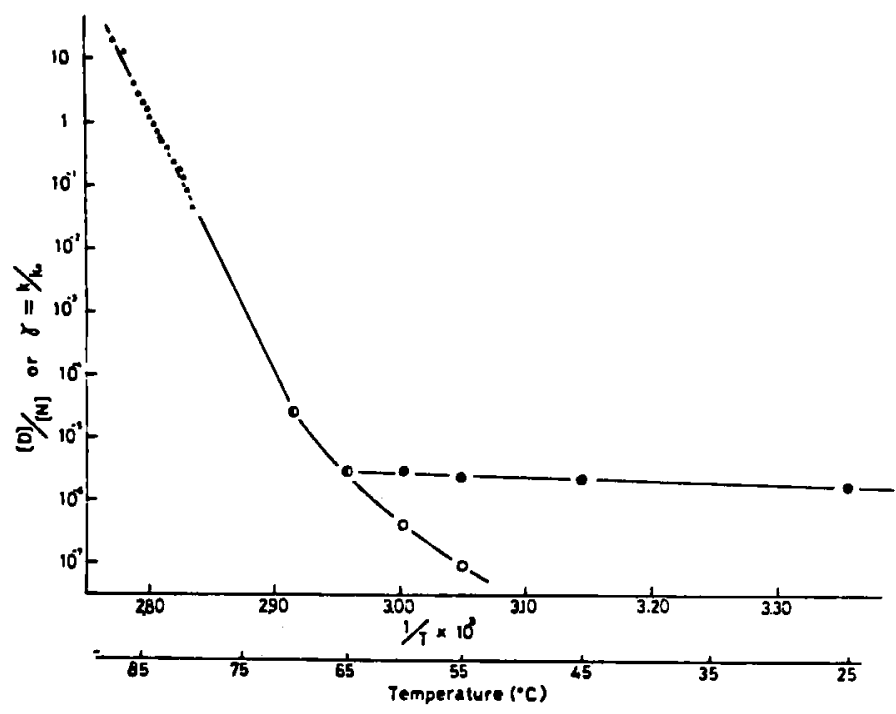

図5 放線菌のズブチリシンインヒビターについてのvan't Hoff プロット. (A) $292 \mathrm{~nm}$ 禁外線吸収で求めた平衙定数. (D)，(O，（O) $k=r \cdot k_{e}$ の関係を使 って速度論的に求めた $r \fallingdotseq[D] /(\mathrm{N})$.

素結合が壤されると同時に疎水結合も 1 個切れると考 えても説明できなくはない.22)しかし，我々はもう少し 可能性の大きなモデルを提出した. それは $D$ 形,つま りあるペプチドの NH基が重水素化される形というの は、その特定の水素結合だけが切れた形ではなく，む ともと切れている水素結合が一力所に集まった形であ ると考えればよく説明できる5),31),33)

このように大多数のタンパク質の重水素交換反応で は, (5)式の仮定が成立しており，交換反応から $D$ 形の 量，「ゆらぎの幅」を求めることができる．ところが， 大豆のトリプシインヒビターでは構造のゆらぎが例外 的にゆっくりであり，むしろ，(3)式が成立していると 考えれば納得できる結果となった．トリプシンインヒビ ターの熱移を紫外吸収スペクトルで測定すると, $\mathrm{pH}$ 2.75 での転移点は $47^{\circ} \mathrm{C}$ 付近である。このものを温 度ジャンプさせ構造変化に伴う吸光度の変化を测定す ると一次反応であることがわかる，その速度定数は

$$
k_{\mathrm{T}-\mathrm{jump}}=k_{1}+k_{2}
$$

で表わせる，平衝定数は

$$
K=\frac{[D]}{[N]}=\frac{k_{1}}{k_{2}}
$$

だから， $k_{1}, k_{2}$ が求まる。その結果は図 6 の○と のようになる。このタンパク質の重水素交換反応の测 定結果を図7に示した.ゆっくり交換する水素は 83 個であり，交換速度定数 $k$ は図 6 のの上うになった。 この $k$ と温度ジャンブからの $k_{1}$ とはよく一致し，(4)式 が成立していることがかかる。転移点付近では $N \rightleftharpoons$ $D$ 変化の半堿期が約 1 時間程度のゆっくりとしたもの である。このようなゆっくりとした構造変化の理由は わからないが， $N \longrightarrow D$ 構造変化に伴って，このタ ンパク中に存在していたわずか $5 \%$ 程度の $\alpha$ ーヘリッ クス構造が $\beta$ 構造に変化することが判明した．図 8 に 椣造変化の前後における赤外吸収のアミド】の差スぺ クトルを示す. $N \rightarrow D$ 変換により $1647 \mathrm{~cm}^{-1}$ の $\alpha-$ ヘリックスの吸収が消失し, $1630 \mathrm{~cm}^{-1}$ の $\beta$ 粠造の吸 収 ${ }^{35)}$ が生じていることがわかる。

3. relaxation spectrum ${ }^{36)}$

ゆっくりと交換する水素の交換は今まで見てきたよ うに数個の一次反応の和として近似できる。しかし, 
(216)

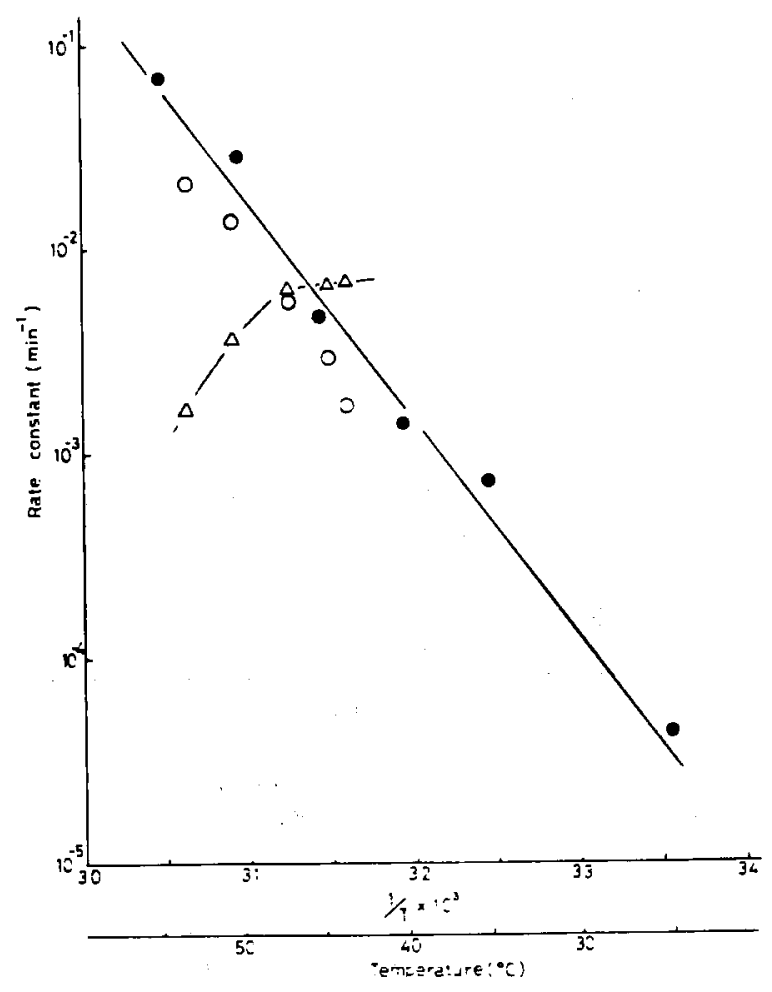

図6大豆トリプシンインヒビターについてのArheniusプロット. Oは温度ジャンプの実験から求めた $N \rightarrow D$ 変化の反店速度定 数, $\triangle$ はその逆反応の速度定数，○は重水素交換反応上り(4) 式から求めた $N \rightarrow D$ 変比の速度定数. $\mathrm{pH} 2.75$.

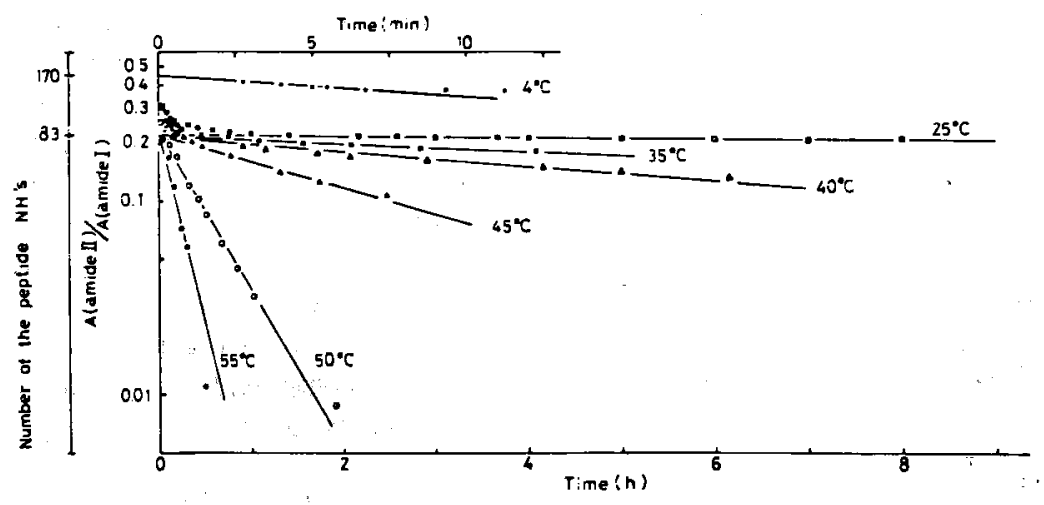

図 7 大豆トリプシンインヒビターの重水素交換の片対数プロット. $\mathrm{pH} 2.75$. 


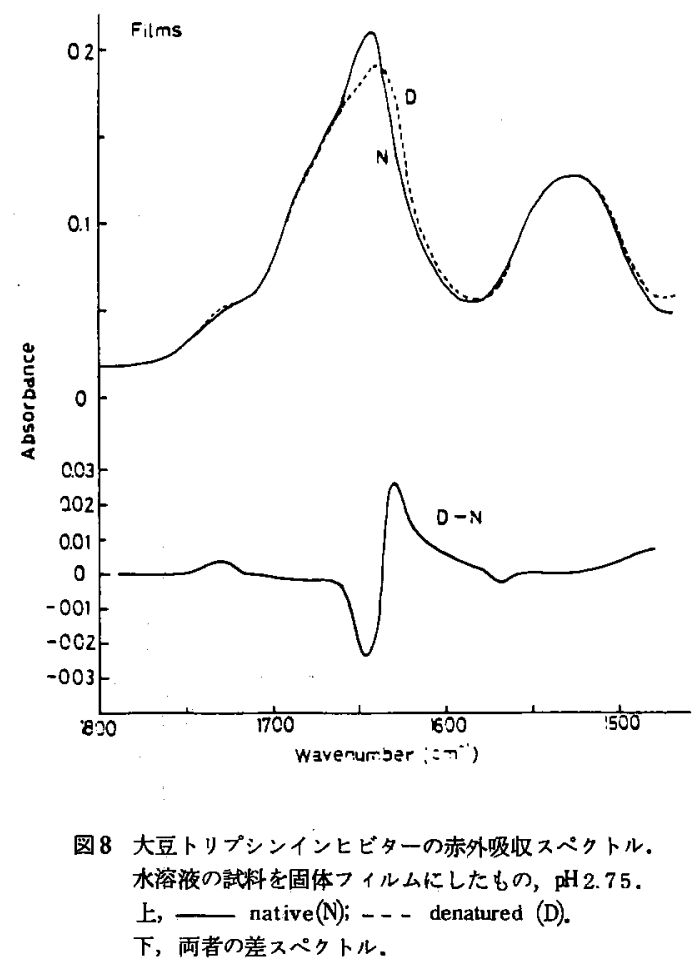

ペプチドのNH基は,これらがタンパク分子中に N個 あればそのN個は皆たがいに環境が異なり，その交換 反応はN個の一次反匛の和としてあらわれているはず である.そ机らを解析することは容易ではないが，

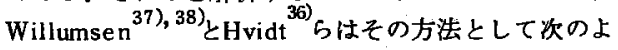
うなものを提案している。

既にみてきたように，タンパク質の同位元素交換反 応は(1)式で記述できると考えられる. また，大多数の タンパク質においては(5)式 ( $\mathrm{EX}_{2}$ 機構) の仮定が成立 していた。この場合, 交換しないで残っているサイト iのペプチド水素の量は，

$$
X_{i}=\exp \left(-r_{i} k_{e} t\right)
$$

で表わせる.ただし， $\gamma_{i}$ は

$$
r_{i}=\frac{\left[D_{i}\right]}{\left[N_{i}\right]+\left[D_{i}\right]}
$$

であり，水素結合が切れて $k_{e}$ で交換できる状態にあ る確率である，むし，あるNH基が完全に自由に溶媒
と接しうる状態にあれば， $\gamma_{i} \doteq 1$ である。一方，水 素結合を維持した native な状態に近ければ， $r_{i}$ は は1よりはるかに小さな值となる。そのような $r_{i} の$ 值はサイト;のゆらぎの幅 ( fluctuation amplitude) を表わしていると考えることができる。

ところで, 式 (10)のように一㮔類の $r_{i}$ 值だと, $\log k_{e} t$ に対し $X_{i}$ をプロットするとその曲線の勾配 は $\gamma_{i}$ の值によらない.なぜなら,

$$
\frac{d \mathrm{X}_{i}}{d \log \left(k_{e} t\right)}=2.30 \mathrm{X}_{i} \ln \mathrm{X}_{i}
$$

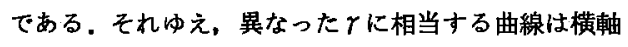
に沿って平行移動すれば重ね合わすことができる， $r_{i}$ $=1 の$ 曲線（図 9 の破線）からの移動する量はー $\log$ $r_{i}$ に等しい(図 9a)）図からわかるように交換する ちちの $90 \%$ は $(-\log \gamma-1)<\log k_{e} t<(-\log r$ +1) の範囲で起こる.しかし, 実際のタンパっ質中 では交換曲線は広い範囲に渡った $\log k_{e} t$ を与え, の值がかなり分布している。っまり， 


$$
\mathrm{X}=\sum_{\mathrm{i}} \exp \left(-r_{i} k_{e} t\right)
$$

と考えねばならない.それゆえ，Hvidt の“ relax-

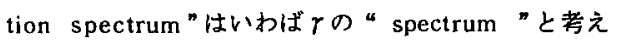
られる。図 9 bは二踵類のケのグルーブが存在すると きの仮想曲線である。二つのグループの交換はよく分 離している。一方，図 $9 \mathrm{c} 、 \mathrm{~d} の$ 例では異なったダル 一プの交換が重複していることがわかる、これらの図 でランダムコィル状態で溶媒と自由に接したポリーD, $\mathrm{L}$ ーアラニンの交換曲線（X= exp $k_{\mathrm{e}} t ）$ は図中の破 線で表わされる。この曲線と特定なタンパク質におけ る曲線の間の面積はそのタンパク質中のすべてのペプ チド残基に対するー $\log \gamma$ の平均值に等しい.すなわ ち,

$$
\begin{aligned}
& \int_{k_{e} t=0}^{\infty} X d \log k_{e} t-\int_{k_{e} t=0}^{\infty} \exp \left(-k_{e} t\right) d \log k_{e} t \\
& =\frac{1}{n} \sum_{i=1}^{n} \int_{k_{e} t=0}^{\infty}\left[\exp \left(-k_{i} t\right)\right. \\
& \left.\quad-\exp \left(-k_{e} t\right)\right] d \log k_{e} t \\
& =-\frac{1}{n} \sum_{i=1}^{n} \log \gamma_{i} \\
& =\langle-\log \gamma\rangle
\end{aligned}
$$

であり， $\gamma_{i}$ が1よりかなり小さ $\left(r_{i}<10^{-2}\right) の$ とき,

$$
\langle-\log r\rangle \cong\langle\log K\rangle=\frac{\langle\Delta G\rangle}{2.30 R T}
$$

となる.ここで,〈 〈

$$
\langle\Delta G\rangle=\frac{1}{n} \sum_{i=1} \Delta G_{i}
$$

であり，各ペプチド残基の $N_{i} \longrightarrow D_{i}$ の構造変化に伴 う自由エネルギー変化の平均值を与える。そして, そ の領域の形はペプチド残基の自由エネルギー変化の個 々の值（ $\Delta G_{i}$ )の分布を示していることになる.Hvidtらはこのようなグラフを“ relaxation spectrum” と呼んでいるず）

\section{4. ミオグロビンの構造のゆらき}

マッコウクジラのミオグロビンの重水素交换反応を pH 5.6〜 7.7, 温度 $0 \sim 55^{\circ} \mathrm{C}$ で测定した結果の一部を 図 10に示した. ${ }^{24)} ゆ っ く り$ 交換する水素の交換反応は 除々に変化してお゙り，数個の一次反応の和として分け

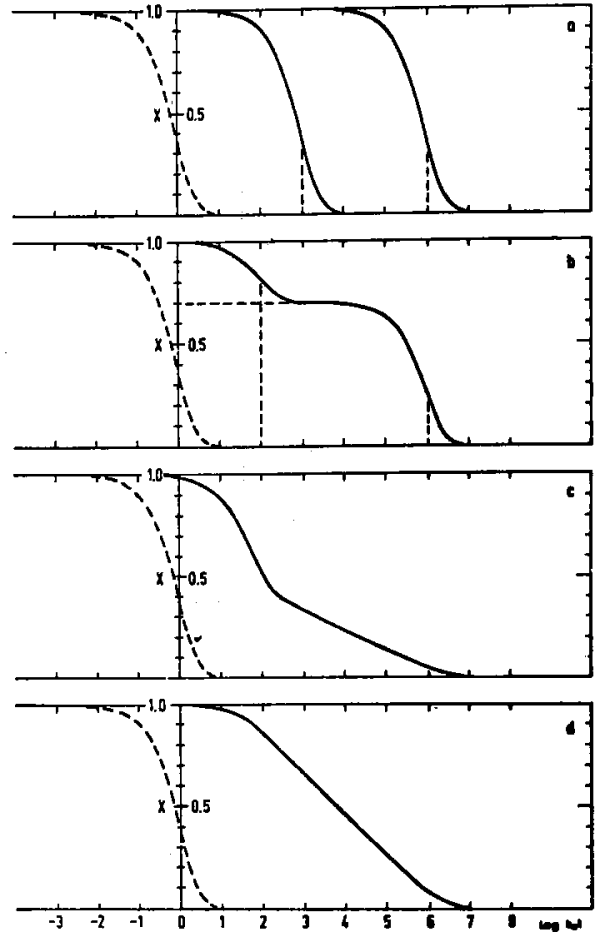

図 9 仮想のタンパク分子に対しXと $\log k_{e} t$ とを計算し た “ relaxation spectra”

破線は完全に溶媒にさらされているぺプチド水素の 交撸を表わす， $\mathrm{X}=\exp \left(-k_{e} t\right)$. 奏線は次のペプチ ドグループの組合せをもった仮想分子に対する計算 曲線. a：全てのべプチド基が $r=10^{-3}$ と $r=10^{-6}$ ; $\mathrm{b}: \mathrm{X}_{1}=0.3, r_{1}=10^{-2} ; \mathrm{X}_{2}=0.7, r_{2}=10^{-6}$ ic: $\mathrm{X}_{1}=\mathrm{X}_{2}=\mathrm{X}_{3}=0.2, \quad r_{1}=4 \times 10^{-2}, r_{2}=2 \times$ $10^{-2}, r_{3}=10^{-2} ; X_{4}=X_{5}=X_{8}=X_{7}=0.1, r_{4}=10^{-3}$, $r_{5}=10^{-4} ; r_{6}=10^{-5}, r_{7}=10^{-6} ; d: X_{1}=X_{2}=X_{3}$ $=\mathrm{X}_{4}=\mathrm{X}_{5}=0.2, r_{1}=10^{-2}, r_{2}=10^{-3}, r_{3}=10^{-4}$, $r_{4}=10^{-5}, r_{5}=10^{-6}$.

ることはかなり困難である。そこで、この反応曲線を “ relaxation spectrum "にプロットしてみた. 図11 はpH 5.6で温度を $0^{\circ} \sim 55^{\circ} \mathrm{C}$ まで変化させたときのる のである. 各温度におけるXと $\log k_{e} t$ の関係はほぼ 一つの曲線上にのっている、ただし，詳細に見ると、 温度が高くなるにつれてわずがつ左側（ $r$ の值が大 きい方向 )にずれていることがかかる。これはpH 5.6 だけでなく他のpH 6.3，7.0，7.7についても同様であ 


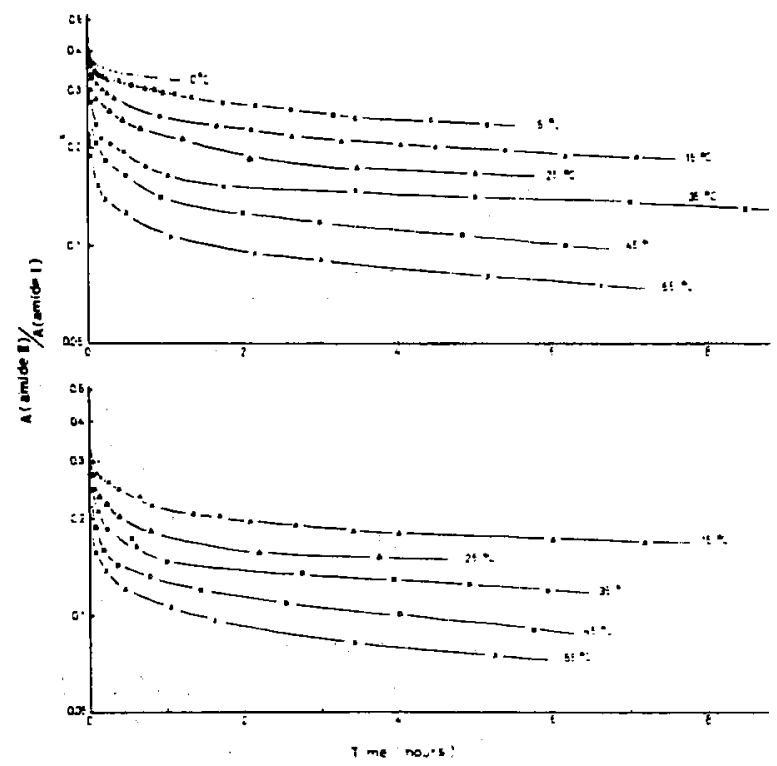

図10 マッコウクジラのミオグロビンの重水素交換反応の片対数グラ 7. 上: pH 5.6, 下: pH6.3.

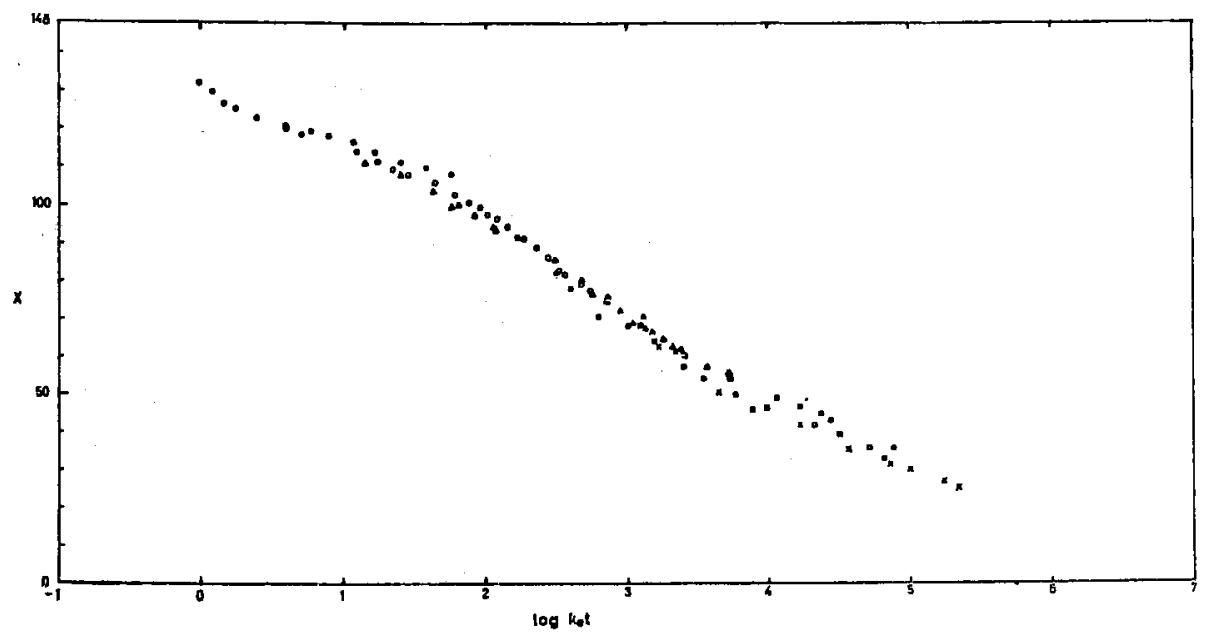

図11ミオグロビンの交换反応の “ relaxontion spectrum”. 図10の上の曲線を再プロットしたもの、○：00， $\mathrm{O}: 5^{\circ} \mathrm{C}, \triangle: 15^{\circ} \mathrm{C}, \triangle: 25^{\circ} \mathrm{C}, \square: 35^{\circ} \mathrm{C}, \square: 45^{\circ} \mathrm{C}, \mathrm{X}: 55^{\circ} \mathrm{C}, \mathrm{pH}$ 5.6. 


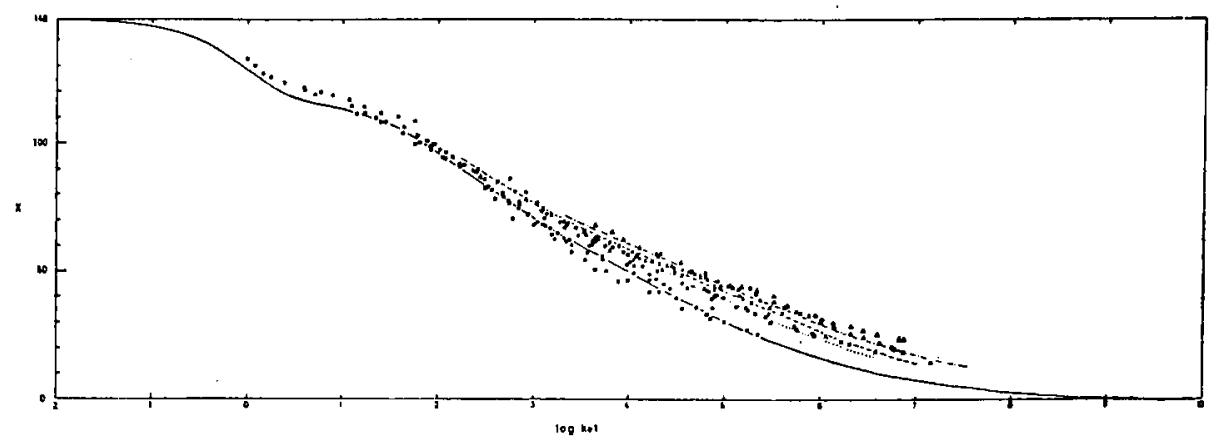

图 12 ミオグロビンの“ relaxation spectrum”の㬰測值と計算值とを比較したグラフ.

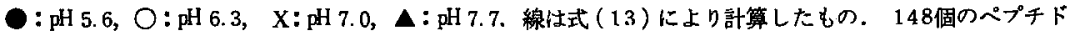

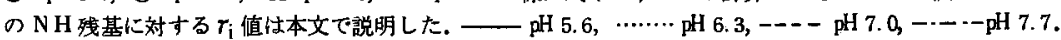

る（図 $12 ）$ このことは交換反忍に対する温度の影 響は $k_{e}$ に対する温度の寄与で大部分表わせることを 示している. つまり, 全てのベプチドの NH基の $r_{i}$ 值が $0 \sim 55^{\circ} \mathrm{C}$ の温度符囲で, 温度の上昇とともにほ んの少しつつ高くなっているだけである。こはリデ チーム, $\alpha$-ラクトアルブミンや S-S1 について既 にふれたことと同じである。熱転移点より $20^{\circ} \sim 25^{\circ} \mathrm{C}$ 以上も低い温度, 寸なわち， native 領域で見られる 橉造のゆらぎの性質の反映である. ${ }^{5), 24), 25) ~ A c a m p o-~}$ raとHermansによってマッコウクジラのミオグロビ ンのpHと温度による変性は吸収スペクトルにより詳し

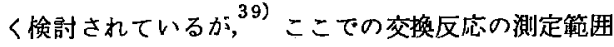
は上の native 領域の条件を满足している.

以上に見てきたように，ミオグロビンのnative領域 での局所的な楞造のゆらぎの振幅は広い分布を持って いた. しかし，現在のところ，特定のペプチド残基に 対し $\gamma_{2}$ を決定することは不可能である.この問題を 解決する一方法として我々は次の上うなモデルを考え てみた.

たとえば， $\boldsymbol{\alpha}$ ーヘリックスの中央部分のペプチドの $\mathrm{NH}$ 基は両端の部分より小さな $て$ の值をしていると考 えてもそれ程おかしくな．合成ポリペプチドの $\alpha-$ ヘリックスに対しても，しばしば考えられていること であり, ${ }^{40), 41)}$ ポリーLーグルタミン酸の重水素交換 反応も $\alpha$ ーへリックスの長さに比例して遅くなること がわかっている. ${ }^{42), 43)}$ さらに, Schoenborn による ミオグロビンの中性子回折の研究結果も上記の考えを 支持している. ${ }^{44)}$ 彼はミオグロビンの結晶を $75 \%$ の 重水中に入れ，一部分重水素化された結晶を得た. そ
の結晶を用いて中性子回折によりミオグロビンの重水 素交換したぺプチド残基の位置を決定した. その結果 を図13に示した。重水素化されていないペプチド残 基はミオグロビンの 8 個の各 $\alpha$ ーリックスの中央に 大体位置していることがわかる．以上の結果などを参 考にして我々はペプチド残基のて值が各へリックスの 端がら内側に進むに従って小さくなっていると仮定し た.

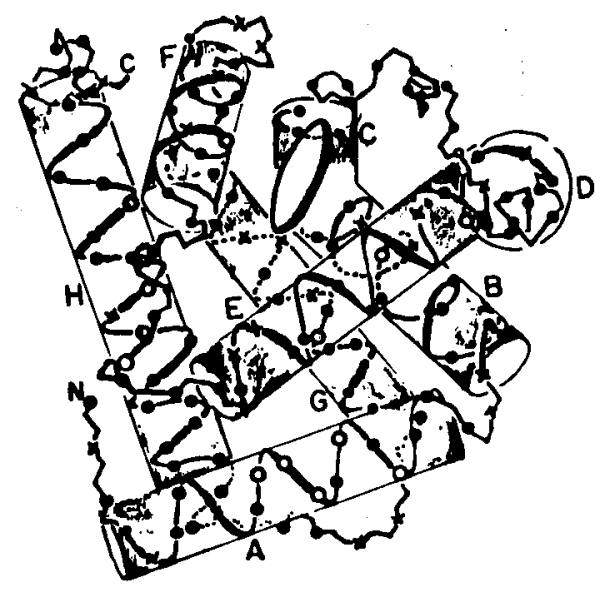

図13ミオグロビンの構造のゆらぎのモデルを示す模式 図. ○重水素化されているペプチドNH基，O重 水素化されていないもの，x不明のもの（Schoenborn $^{44)}$ に上る). 
ところで， $\Delta F_{i}$ を $N_{i} \rightarrow D_{i}$ 転移における自由エネ ルギーの変化とすると,

$$
r_{i}=\exp \left(\frac{-\Delta F_{i}}{k T}\right)
$$

である、ただし， $k$ は Boltzmann 定数. $T$ は絶対温 度である。ここで，端からn番目の残基の自由エネル ギー変化 $\Delta F_{n}$ が

$$
\Delta F_{n}=\Delta F_{\ell}+(n-1) \Delta F_{s}
$$

で与えられると仮定した.つまり，ヘリックスの端の ペプチド残基の $N \rightarrow D$ 変化の自由エネルギー変化を $\Delta F_{t}$ とし,ミオグロビン中の各 $\alpha$ ーヘリックスの末端 以外のペプチドーペプチドの水素結合の切れるときの自由エ ネルギーの変化端に近方の隣接したペプチドの水素結 合が切れるときの自由エネルギー変化に $\Delta F_{s}$ を加えた ઢのと考えている. $\mathrm{pH} 5.6,25^{\circ} \mathrm{C}$ で $\Delta F_{t}=2.86$, $\Delta F_{s}=0.82 \mathrm{kcal} / \mathrm{mol}$ で実験結果を充分に説明でき ることがかかった. それぞれのpHにおける計算による Xと $\log k_{e} t$ の曲線は図 12 の実線及び破線のように なる.

\section{5. 他分子との相互作用と構造のゆらぎ}

S chechter らはぶどう状球菌のヌクレアーゼ(Staphy lococcus nuclease) にデオキシチミジンー3, $5^{\prime}$ 二 リン酸やカルシウムイオンが結合すると、 ヌクレテー
ゼ中の一部の交換速度が㧕制されることを報告してい

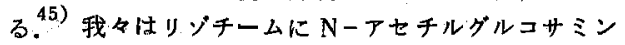
のオリコマーが結合したときにも棈造のゆらぎが抑制 されることを明らかにした. ご これらの例からもモ， マー酵素では基留とか阻害剤が結合したとき構造のゆ らぎは抑制されると考えてよい。

一方，Printzと Gouvarisは酵母ピルペートデカ ルポキシラーゼ( Pyruvate decarboxylase)の檴造変 化に対する基翼及び阻害剂の効果をトリチウムー水 素の交換により研究している. ${ }^{46)}$ 酵母のピルベートデ カルポキシラーゼはサプュニットからなる分子量 208,000のタンパク質でありピルビン酸を脱炭酸し てアセトアルデヒドを生する反応

$$
\mathrm{CH}_{3} \mathrm{COCOOH} \rightarrow \mathrm{CH}_{3} \mathrm{CHO}+\mathrm{CO}_{2}
$$

を触媒する酵素である. 補醭素として活性部位にチア ミン二リン酸を要求する.この補酵素性醳素活性のあ るpH 6 から 7 の領城では holo 酵素からは解離しない. $\mathrm{pH} \mathrm{6.5}, 0^{\circ} \mathrm{C}$ で交換反応を測定すると 1600 個のてミ ド水素のうち850個の交換反応を測定でき，非常に ゆっくりと交換する水絜は 225 個，全体の $14 \%$ であ った(図 14 の実線).

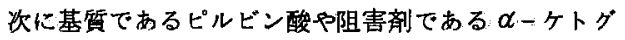
ルタル酸や塩化第二水銀を加えて交換反応を測定した

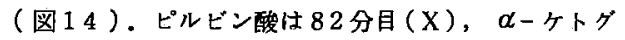
ルタル酸は 72 分目 (口), また, 塩化第二水銀とピル

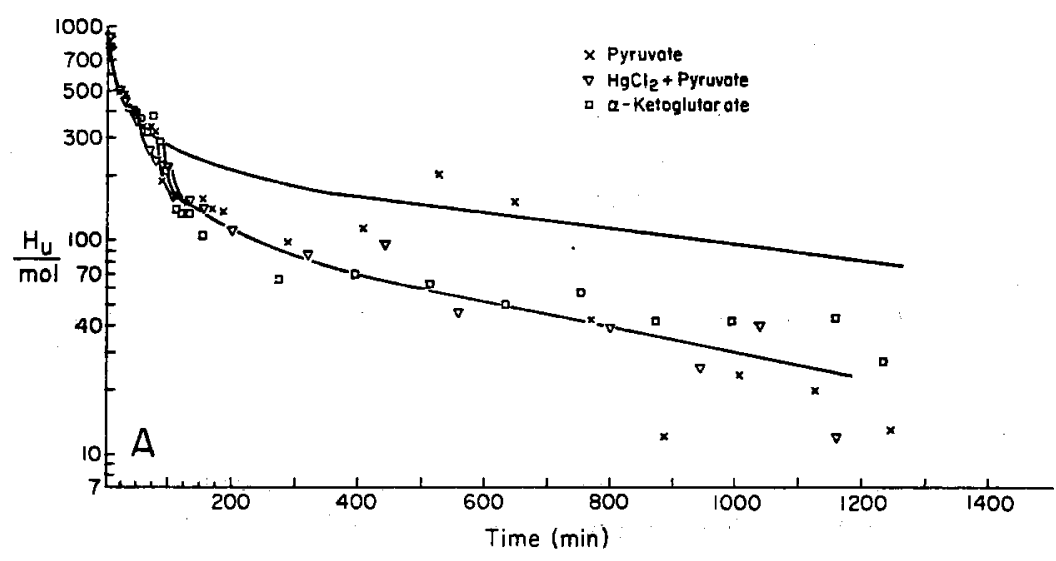

図 14 ピルベートデカルボキシラーゼの T-H 交換の図. 上の実䮖は酵素だけのときの交換曲線.

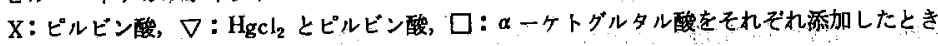
の反応曲線. $\mathrm{pH} 6.5,0^{\circ} \mathrm{C}$. 
ビン酸を 43 分目と102分目 $(\nabla)$ に加えた夷䟻結果で 南る. 3 つの実験とも非常にゅっくりと交換する水素 の $50 \%$ が素早く交換するようになる。この锩素は $\alpha$ 一ケト酸に特異性をもって打り，乳酸やホルムアルデ ヒドとは結合しない，それゅえ，交换反応に対才る影 響もみられなかった。これらの物誓は䣼素の共通の領 减の構造変化を来たしていると考えられる。この醅素 は基質の結合によりサプュニットに解離するかけではな い. 基質（または阻害剤）の結合に伴って構造のゆら ぎが增大し、酻素の活性部位に近うきやすくなり, 活 性の維持を容易にすると考えられる。これはアロステ リックな酥索における調節とよく類似しており，サブ ニニット間の相互作用の変化をも含んでると考えら れる. Englander らがへモグロビンの Oxy 型と Deoxy 型について得た結論と同しであり, ${ }^{47), 48)}$ 醉素 のフロステリックな調節に栱造のゆらぎの変化が重要 な役割をはたしていることを示唆している.

\section{6. 側鎖の水素の交換}

一般に側鎖の構造のゆらぎは主鎖よりも大きいと想 像されるし，その動きは機能の発現と直接関保してい ると考えられる。側鎖の交换反応の測定はペプチド水 素ほど容易ではないが、正確な残基の位置が決定でき る場合がある。これらについては核磁気共鳴 (N MR) でタンパク中のトリプトファンのインドールの NHと七 スチジンの $\mathrm{C}_{2}-\mathrm{H}$ の水素の䂭换反测定されてい る.99), 50),51) また, ラマンスペクトルによっていリジ

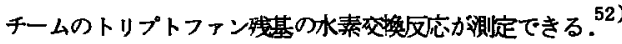

ヒスチジン残基の二つの窒素にはさまれた 2 位の炭 素に結合した水素は非常にゆっくりではあるが溶媒の 水の水素と交換する.このゆっくりと交換する特徴を 生かして，交換がある程度進行したタンパク睤をタン パク分解蟀素で限定分解した後，クロマトグラフにか けて分解物を分離するなどの操作をすれば，交換する 残基の正確な位置の決定ができる.NMRではこの $\mathrm{C}_{2}$ - $\mathrm{H}$ のプロトンは芳香環水素のシグナル位置より 少し低磁場にヶミカルシフトを持つ，Meadowsらは リボヌクレアーゼAのNMRを測定し，4個のヒス千 ジン残基の適定曲楾を求めた. 年同時に重水中で徐々に この水素が重水素と交換することを報告した，その後， J. H. Bradbury はこの 4 個の水素の交換反応を追跡 している.

我々は $\alpha$ ーラクトアルプミン中の 3 個のヒスチジン

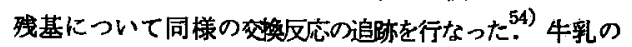
๙ーラクトアルブミンは卵白リゾチームと一次棬造が
よく類似していることから高次構造も類似しているだ ろうと想像されているタンパク質である。ローラクト アルブミンの3 個のヒスチジン残基(His) はN末端 から 32，68，107 番目の位㯰にある. NMR スペ クトルにおける 3 個の $\mathrm{C}_{2}-\mathrm{H}$ のピークに対し残基の 位固の決定をモノヨード酶酸による反応性の違い ${ }^{53} に$

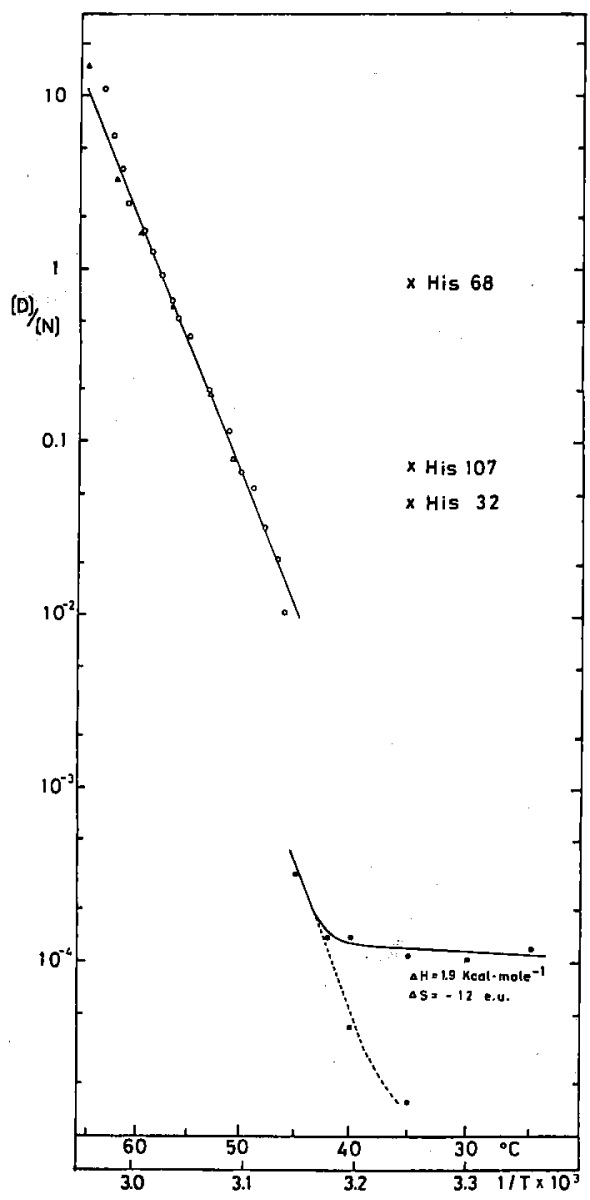

图15aーラクトアルブミンについての各喠平衝定数 ([D] $/[\mathrm{N}])$ ) van't Hoff プロット. $\mathrm{O}$ : 紫外爱収 ( 292nm), $\Delta$ : 円二色性スペク トル $(222 \mathrm{~nm})$ ，の:ペプチド基の重水素交換， $\mathrm{X}=$ 七 スチジン残基の $\mathrm{C}_{2}$-Hの水素の 交换反店 のそれぞれから求めたもの. 


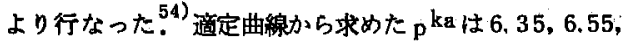

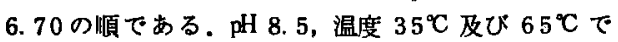
$\mathrm{C}_{2}-\mathrm{H}$ の水素の重水素交換反応を測定すると，交 換反応はそれぞれ一次反応で進行する．この場合も(1) 式の上うな機搆で交換反応が進行すると仮定すると，

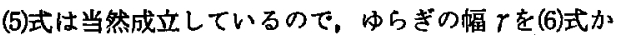
ら求められる。 $k$ としてはアミ/酸のヒスチジンの ものを用いた ${ }^{55)} 65^{\circ} \mathrm{C}$ では3 個のヒスチジン残基の $r$

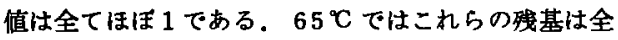
て完全に溶媒と自由に接していることになる， $\alpha$ ラ クトアルブミンがこの温度では完全に変性した構造を とっていることから ${ }^{25)} し て$ 当然のことのようである.

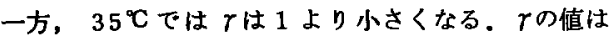
His 32 が 0.04 , His 107 は 0.07 でほ同程度 の值である。一方, His 68 は 0.46 と大きな值をし めし，50\%程度に溶媒との接触の自由度が下げられ ているにすぎない，His 68 は NMRの線幅む他の二 つの残基に比べ挟く運動性が大きいと考えられる。こ れは交換反応と同一の傾向を示している， アルブミンの水素結合をしたペプチド水素の rの值と 比較してヒスチジンの值をプロットしたのが図 15 で ある、両者のゆらぎの振幅の違いがわかる. 25),54)

同位元素交換法によってタンパク質の主鎖を中心に 側鎖に関しても少しずつ構造の摇動の様子がわかって きた。 それらをタンパク分子の各部分部分について詳 細に記述していくことが今後の課題であろう。

本研究および本稿の執筆にあたり，御指導，御助言 をいただきました坪井正道教授に感謝いたします。

\section{文献}

1) M. O. Dayhoff : Atlas of Protein Sequence and Structure, 5, 27, National Biomedical Research Foundation, Silver Spring, Md, U. S. A.

2) A. Hvidt, K. Linderst $\phi \mathrm{m}$-Lang : Biochim. Biophys. Acta., 14, 574, (1954)

3) K. Linderstr $\phi m-L a n g$ : Chem. Soc. Spec. Puble., 2, 1 (1955)

4) M. Nakanishi, M. Tsuboi, A. Ikegami : J. Mol. Biol., 70, 351 (1972)

5) M. Nakanishi, M. Tsuboi, A. Ikegami : J. Mol. Biol., 75, 673 (1973)

6) M. Nakanishi, M. Tsuboi; J. Mol. Biol., 83, 379 (1974)
7) S. W. Englander, N. W. Downer, H. Teitelbaum : Ann. Rev. Biochem., 41, 903 (1972)

8) 坪井 正道, 中西 守：化学の領域，28，458 (1974)

9) A. Hvidt, S. O. Nielsen : Advan. Protein. Chem., 21, 287 (1966)

10) S. W. Englander : Biochemistry, 2, 798 (1963)

11) E. R. Blout, C. de Lozé, A. Asadourian : J. Amer. Chem. Soc., 83, 1895 (1961)

12) S. Beychok, C. de Lozé, E. R. Blout : J. Mol. Biol., 4, 421 (1962)

13) L. Pauling, R. B. Corey, H. R. Branson : Proc. Natl. Acad. Sci. U. S. A., 37, 207 (1951)

14) M. Nakanishi, M. Tsuboi : Bull. Chem. Soc. Japan, 47, 305 (1974)

15) S. W. Englander, R. Staley : J. Mol. Biol., 45 277 (1969)

16) R. E. Canfield : J. Biol. Chem., 238, 2698 (1969)

17) A. B. Edmundson : Nature, 205, 883 (1965)

18) B. S. Hartley : Nature, 201, 1284 (1964)

19) B. Kassell, M. Laskowski : Biochem. Biophys. Res. Commun., 20, 463 (1965)

20) G. M. Edelmann, B. A. Cunningham, G. N. Reeke, J. W. Becker, M. J. Waxdal, J. L. Wang : Proc. Natl. Acad. Sci. U. S. A., 69, 2580 (1972)

21) K. Brew, T. C. Vanaman, R. L. Hill : J. Biol. Chem., 242, 3747 (1967)

22) T. Koide, T. Ikenaka : Eur. J. Biochem., 34, 417 (1973)

23) S. Murao, S. Sato : Agr. Biol. Chem., 36, 160 (1972)

24) M. Nakanishi, M. Tsuboi, A. Ikegami : Bull. Chem. Soc. Japan, 47, 293 (1974)

25) H. Takesada, M. Nakanishi, M. Tsuboi : J. Mol. Biol., 77, 605 (1973)

26) D. C. Phillips : Scientific American, 215, 78 (1966)

27) J. C. Kendrew, R. E. Dickerson, B. E. Strandberg, R. G. Hart, D. R. Davies, D. C. Phillips, V. C. Shore : Nature, 185, 422 (1960) 
28) J. J. Birktoft, D. M. Blow : J. Mol. Biol., 68, 187 (1972)

29) R. Huber, D. Kukla, A. Rühlman, W. Steigemann : Cold Spr. Har. Symp. Quant. Biol., 36, 141 (1971)

30) R. S. Molday, S. W. Englander, R. G. Kallen : Biochemistry, 11, 150 (1972)

31) M. Nakanishi, M. Tsuboi : to be published.

32) W. Kauzmann : Advan. Protein Chem., 14, 37 (1959)

33) 坪井 正道：現代化学，1973 年 1 月号, $\mathrm{p} 46$

34) K. Hamaguchi, A. Kurono, S. Goto : J. Biochem. (Tokyo), 54, 259 (1963)

35) T. Miyazawa, E. R. Blout : J. Amer. Chem. Soc., 83, 712 (1961)

36) A. Hvidt, K. Wallevik : J. Biol. Chem., 247, 1530 (1972)

37) L. Willumsen : Biochem. Biophys. Acta., 126, 382 (1966)

38) L. Willumsen : Compt. Rend. Trav. Lab. Carlsberg, 38, 223 (1971)

39) G. Acampora, J. Hermans : J. Amer. Chem. Soc., 89, 1543 (1967)

40) R. L. Snipp, W. G. Miller, R. E, Nylund : J. Amer. Chern. Soc., 87, 3547 (1965)

41) B. H. Zimm, J. K. Bragg : J. Chem. Phys., 31, 526 (1959)

\section{ABSTRACT}

42) M. Nakanishi, M. Tsuboi, A. Ikegami, M. Kanehisa : J. Mol. Biol., 64, 363 (1972)

43) A. Ikegami, M. Kanehisa, M. Nakanishi, M. Tsuboi : Advan. in Biophys., 6, 1 (1974)

44) B. P. Schoenborn : Cold Spr. Harb. Symp. Quant. Biol., 36, 569 (1971)

45) A. N. Schechter, L. Morávek, C. B. Anfinsen : J. Biol. Chen., 244, 498 (1969)

46) M. P. Printz, A. D. Gounaris : J. Biol. Chem., 247, 7109 (1972)

47) S. W. Englander, C. Mauel : J. Biol. Chem., 247, 238 (1972)

48) S. W. Englander, A. Rolfe : J. Biol. Chem., 248, 4852 (1973)

49) J. D. Glickson, W. D. Phillips, J. A. Rupley : J. Amer. Chem. Soc., 93, 4031 (1971)

50) D. H. Meadows, O. Jardetzky, R. M. Epand, H. H. Ruterjans, H. A. Sheraga : Proc. Natl. Acad. Sci. U. S. A., 60, 766 (1968)

51) J. H. Bradbury, B. E. Chapman : Biochem. Biophys. Res. Commun., 49, 891 (1972)

52) M. Nakanishi, M. Tsuboi : to be published.

53) F. J. Castellino, R. L. Hill : J. Biol. Chem., 245, 417 (1970)

54) H. Takesada, M. Nakanishi, M. Tsuboi, K. Ajisaka : Biopolymers, to be published (1974)

55) J. H. Bradbury, B. E. Chapman, F. A. Pellegrino : J. Amer. Chem. Soc., 95, 6139 (1973)

Fluctuation of the Protein Structure

Mamoru NAKANISHI

Faculty of Pharmaceutical Sciences, University of Tokyo

Recent progress in the understanding of hydrogen exchange and its use in studies of the fluctuation of the protein structure are reviewed. By means of an infrared spectroscopic observation of the hydrogen exchange reaction, a simple and reliable method of determining the number of the peptide-peptide hydrogen bonds in a given protein molecule in its aqueous solution is proposed. Then, the mechanisms of hydrogen exchange in protein are critically examined comparing hydrogen exchange kinetics with other physical method for several proteins. The graphic method of evaluation of the fluctuation amplitude at various levels and the results of its application to myoglobin structure are shown. In addition, the fluctuation of the side chain is also discussed. 